\title{
Pacitanian Art-Edu \\ (Jalan Alternatif Menuju Hakekat Tujuan Pendidikan Seni di Indonesia)
}

\author{
Deasylina da Ary \\ Jurusan Pendidikan Guru Sekolah Dasar (PGSD), Fakultas Ilmu Pendidikan (FIP), \\ Universitas Negeri Semarang (UNNES) \\ deasy_dance@yahoo.com
}

Pelaksanaan pendidikan seni di lapangan saat ini sudah bergeser dari hakekat tujuan pendidikan sesungguhnya. Pendidikan seni tari di lapangan saat ini memakai metode reproduksi atau imitasi, dimana tidak ada ruang untuk mengembangkan kreativitas, imajinasi, serta ruang untuk memahami diri sendiri dan lingkungannya. Perlu adanya sebuah model pendidikan seni yang berorientasi terhadap lingkungan. Sebuah model pendidikan yang menitikberatkan pada perkembangan kreativitas dan imajinasi anak, serta berorientasi pada lingkungan melalui wahana seni. Potensi sungai, gua, dan pantai di Kabupaten Pacitan yang menyimpan jejak kehidupan manusia purba di dalamnya, sangat menginspirasi untuk dijadikan sebagai laboratorium sample pencarian model pendidikan ini. Maka ditemukanlah Pacitanian Art-Edu yang dapat menjawab persoalan pelaksanaan pendidikan seni saat ini. Pacitanian Art-Edu merupakan sebuah model pendidikan yang menempatkan fenomena lingkungan alam Pacitan yang menyimpan jejak kehidupan prasejarah di dalamnya, sebagai orientasi utama. Seni dijadikan sebagai wahana, dengan materi latihan ketubuhan di lingkungan alam Pacitan. Pacitanian Art-Edu merupakan hasil dari sebuah proses penciptaan karya seni Pacitanian (Model Pendidikan Berorientasi Lingkungan) yang telah dipergelarkan pada tanggal 27 Januari 2017 yang lalu. Proses kreatif yang telah dirintis sejak tahun 2010 dan lebih mengerucut pada tahun 2014. Proses yang dilalui adalah penghayatan kehidupan prasejarah melalui citra visual (film, museum dan situs), pengayaan informasi (buku, browsing, dan penggalian informasi dari ahli), latihan kepekaan tubuh di lingkungan, pencarian permainan inovasi, dan workshop-workshop.

Kata kunci: pendidikan, seni, lingkungan

\section{Pacitanian Art-Edu \\ (Alternative Paths to the Essence of the True Purpose of Art Education in Indonesia)}

The implementation of art education in the field has now shifted from the essence of the true purpose of education. Nowadays, dance education in the field uses reproduction or imitation methods, where there is no room to develop creativity, imagination, and space to understand oneself and their environment. Thus, it needs a model of art education that is oriented towards the environment. An educational model that focuses on the development of children's creativity and imagination, as well as being environmentally oriented through arts. The potential of rivers, caves, and beaches in Pacitan Regency which keeps traces of ancient human life in them, is very inspiring to be utilized as a sample laboratory for this educational model study. So Pacitanian Art-Edu is found to answer the issue of the implementation of art education today. Pacitanian Art-Edu is an educational model that places the Pacitan natural environment phenomenon that holds traces of prehistoric life in it, as the main orientation of study. Art is used as a tool, with body training material in the natural environment of Pacitan. Pacitanian Art-Edu is the result of a process of creating Pacitanian art (the Environmentally Oriented Education Model) which was performed on January $27^{\text {th }}, 2017$. The creative process that has been pioneered since 2010 and has become more conical in 2014. The process involves prehistoric life appreciation through visual imagery (films, museums and sites), enrichment of information (books, browsing, and extracting information from experts), body sensitivity training in the environment, searching for innovation games, and workshops.

Keywords: education, art, environment

Proses Review : 1 - 18 April 2019, Dinyatakan Lolos: 22 April 2019 


\section{PENDAHULUAN}

Idealnya, sebuah proses pendidikan harus mampu menumbuhkan dan sekaligus mewadahi kreativitas dan imajinasi anak, serta berorientasi pada memahami diri sendiri dan lingkungannya. Akan tetapi kenyataan yang terjadi di lapangan saat ini, pendidikan lebih ditekankan pada proses mentransfer pengetahuan dan keterampilan.

Yudi Latif dalam tulisannya di Kompas pada Kamis, 4 Agustus 2016 berjudul "Pendidikan Tanpa Mendidik" menyayangkan pelaksanaan pendidikan di Indonesia yang tidak sesuai lagi dengan hakikat pendidikan sesungguhnya. Pendidikan lebih diartikan sebagai pengajaran (onderwijs), yakni pemberian materi yang sarat muatan kognitif seperti pengetahuan dan keterampilan. Padahal pendidikan (education) merupakan proses belajar menjadi manusia seutuhnya, yang dilakukan sepanjang hayat dengan menuntun mengeluarkan potensi-potensi bawaan anak agar bertumbuh sehingga dapat mencapai keselamatan dan kebahagiaan yang setinggi-setingginya.

Pelaksanaan pendidikan yang telah bergeser dari hakikat tujuan pendidikan ini juga terjadi pada proses pendidikan seni. Pelaksanaan pendidikan seni tari di lapangan yang ada saat ini, pada umumnya lebih menekankan kepada metode reproduksi atau imitasi, yaitu kegiatan belajar menarikan kembali sebuah tarian yang diajarkan oleh guru dengan cara menirukan gerak guru secara mekanis. Anakanak dituntut untuk memiliki keterampilan seni seperti yang diharapkan oleh seorang guru. Dalam hal ini peluang untuk mendidik anak menjadi manusia sesungguhnya yang mempunyai daya imajinasi dan kreatifitas sangatlah minimal. Tidak ada peluang untuk lebih mengenal potensi-potensi yang dimiliki olehnya dan lingkungannya.

Oemar Hamalik menyatakan bahwa lingkungan memegang peranan penting dalam pendidikan karena sangat berpengaruh terhadap tingkah laku seorang individu. Lingkungan dalam hal ini bisa berupa lingkungan sosial, personal, alam atau fisik, dan kultural. (2003:194-195)

Pendidikan berdasarkan lingkungan akan membantu anak didik untuk menyesuaikan dirinya dengan keadaan sekitarnya, sehingga akan mempengaruhi pembentukan dan pengembangan kepribadian dan potensi mereka sebagai manusia yang akan hidup di masyarakat. Ovide Decroly melontarkan teori Ecole pour la vie par lavie, bahwa "Sekolah adalah dari kehidupan dan untuk kehidupan" (Oemar Hamalik, 2003:193).

Berdasarkan latar belakang tersebut sangatlah perlu adanya sebuah model pendidikan seni yang berorientasi terhadap lingkungan. Sebuah model pendidikan yang menitikberatkan pada perkembangan kreativitas dan imajinasi anak, serta berorientasi pada lingkungan melalui wahana seni. Melalui seni anak dapat mempunyai kreativitas dan kepekaan terhadap lingkungan untuk menjalani kehidupan dan juga mempertahankan hidupnya.

\section{METODE PENCIPTAAN}

Proses penciptaan dimulai dengan melakukan kerja riset terhadap pelaksanaan pendidikan seni dan potensi Kabupaten Pacitan dimulai sejak tahun 2010 sampai dengan januari tahun 2017. Proses ini dilakukan dengan cara mengumpulkan data-data dengan cara observasi lapangan, wawancara, maupun study kepustakaan.

Setelah data-data terkumpul maka mulai membuat rumusan-rumusan untuk proses kreatif selanjutnya yang melibatkan anak-anak. Proses yang telah dilalui adalah sebagai berikut:

Penghayatan kehidupan prasejarah melalui citra visual (film, museum dan situs): Untuk memperkenalkan kehidupan prasejarah kepada anak-anak, maka diputarlah film tentang kehidupan prasejarah. Proses yang telah dilakukan hingga saat ini adalah:

a. Mencari referensi film-film tentang kehidupan prasejarah.

b. Mengaplikasikan hasil melihat film prasejarah.

c. Mengunjungi museum prasejarah.

d. Mengunjungi situs-situs prasejarah

Pengayaan informasi (buku, browsing, dan penggalian informasi dari ahli)

a. Pencarian buku-buku dan gambar-gambar prasejarah.

b. Penggalian informasi dari internet

c. Penggalian informasi dari ahli. Wawancara telah dilakukan dengan Harry Widianto, seorang ahli Paleoantropologi. Wawancara ini bertujuan untuk menggali informasi dan pengetahuan tentang kehidupan prasejarah di lingkungan Pacitan.

Pencarian permainan inovasi. Kegiatan pencarian permainan inovasi ini sangat diperlukan dengan alasan sebagai berikut:

a. Menyesuaikan dengan lingkungan;

b. Menyesuaikan dengan kebutuhan latihan;

c. Menciptakan suasana latihan baru yang tidak membosankan;

d. Membuat anak termotivasi.

Permainan yang telah dihasilkan dan telah dilaksanakan adalah:

a. Permainan Menirukan Binatang

b. Permainan Apa Ini Apa Itu

c. Permainan Predator dan Mangsa

d. Permainan Imajinasi

e. Permainan Wek Wek Gung

f. Permainan Coca Cola Disco

g. Permainan Ulå-ulånan

h. Permainan Dhorémidhosål 


\section{Workshop-workshop}

Dengan mendatangkan pemateri yang ahli di bidangnya, pelaksanaan workshop ini bertujuan untuk memberikan tambahan pengetahuan dan pengayaan kepada anak-anak.

a. Workshop menggambar bebas (I Wayan Sujana Suklu-Bali). Menurut I Wayan Sujana Suklu, workshop ini sangat penting bagi anak supaya anak dapat membebaskan jiwanya untuk berkreasi terbebas dari aturan-aturan yang mengungkung di tiap detik kehidupan mereka. Selain itu, melalui workshop ini juga dapat dilatih konsentrasi dan kecepatan refleks serta estetika jiwa mereka.

b. Workshop Multimedia (Andy Donovan-Australia). Melalui workshop yang dilaksanakan selama dua hari ini, anak-anak mengenal bagaimana membuat video mapping, mulai dari persiapan, pembuatan video sederhana, sampai dengan pemasangan alat dan perlengkapan untuk memutarnya.

c. Workshop musik dan gerak dalam gua (Medeleine Flynn, Tim Humprey \& Tony Yap-Australia). Workshop ini dilakukan di Gua Tabuhan dengan tujuan untuk mengajak anak-anak mengenal bunyi nada dan bermain-main dengan suara gaung dan gema di berbagai ruangan berbeda di dalam gua tabuhan. Selain itu anak-anak juga diajak untuk bergerak secara bebas mengikuti bunyi yang dihasilkan tersebut.

Latihan kepekaan tubuh di lingkungan

Tujuan yang ingin dicapai melalui kegiatan ini antara lain: Mengajak anak-anak bereksplorasi, menjelajah dan mengenal lingkungan, membentuk stamina tubuh anak, melatih kepekaan tubuh atau motoric sense baik secara visual maupun auditif, berlatih kepekaan dalam hubungan emosional dengan lingkungan sekitarnya (latihan kepekaan artistik).

Latihan ini dilakukan secara bertahap di lingkungan berbeda, yaitu:

a. Latihan di Hutan Jati/Tahap Awal/Pra Embrio. Latihan ini merupakan tahap riset awal yang dimulai sejak tahun 2010. Pengkarya mencoba untuk memberikan pemahaman terhadap permasalahan lingkungan yang sedang melanda yaitu tentang penebangan hutan secara besar-besaran.

b. Latihan di Gua Tabuhan \& Lukisan gua (Cave Painting) / Terminal 1

\section{Observasi}

Gua Tabuhan terletak di Desa Wareng, Kecamatan Punung, Kabupaten Pacitan. Gua ini merupakan situs hunian gua tertua di Asia Tenggara, sekitar 60.000 tahun hingga 30.000 tahun yang lalu, dengan tinggalan berupa fauna dan artefak litik (Truman Simanjuntak, 2004:82).

Berdasarkan hasil observasi, maka diperoleh gambaran tentang kondisi gua, dan bagaimana gua ini akan dimanfaatkan sebagai tempat latihan sekaligus juga sumber inspirasi dalam proses latihan yang akan berlangsung.
Latihan di Gua Tabuhan

Latihan di Gua Tabuhan ini untuk mengaplikasikan data-data yang telah diperoleh selama penelitian ke dalam sebuah model pendidikan seni yang berorientasi lingkungan. Hasil yang diharapkan dari proses ini adalah terciptanya sebuah model pendidikan yang berorientasi lingkungan, menarik, dan inovatif.

\section{c. Latihan di lingkungan Sungai Janglot / Terminal 2} Observasi

Setelah berkeliling mengamati sungai-sungai yang ada di sekitar kecamatan Punung dan Pringkuku, serta keterkaitan antara sungai-sungai tersebut dan situs Sungai Baksoka, maka dipilihlah Sungai Janglot sebagai lokasi penelitian kedua.

Berdasarkan hasil observasi, maka diperoleh gambaran tentang kondisi sungai, dan bagaimana sungai ini akan dimanfaatkan sebagai tempat latihan sekaligus juga sumber inspirasi dalam proses latihan.

\section{Latihan di Sungai Janglot}

Latihan di Sungai Janglot ini untuk mengaplikasikan data-data yang telah diperoleh selama penelitian ke dalam sebuah model pendidikan seni yang berorientasi lingkungan. Hasil yang diharapkan dari proses ini adalah terciptanya sebuah model pendidikan yang berorientasi lingkungan, menarik, dan inovatif.

\section{d. Latihan di lingkungan pantai Srau/Terminal 3 Observasi}

Pantai Srau merupakan pesisir Gunung Sewu yang merupakan sumber situs kehidupan prasejarah. Daerah pesisir adalah wilayah eksploitasi (catchman area) manusia prasejarah untuk pemanfaatan biota laut, perburuan binatang dan pemanfaatan biji-bijian. Fosil biota laut dari pesisir pantai ini banyak ditemukan di dalam penguburan di dalam gua-gua yang tersebar di Asia Tenggara bersama dengan fosil tulang manusia prasejarah. Termasuk juga di dalam situs Song Keplek yang terletak di Kecamatan Punung Kabupaten Pacitan (Simanjuntak, 2004:105). Alasan tersebut yang mendasari pemilihan lingkungan untuk latihan di tahap yang ketiga ini.

\section{Latihan di Pantai Srau}

Latihan di pantai Srau ini untuk mengaplikasikan data-data yang telah diperoleh selama penelitian ke dalam sebuah model pendidikan seni yang berorientasi lingkungan. Hasil yang diharapkan dari proses ini adalah terciptanya sebuah model pendidikan yang berorientasi lingkungan, menarik, dan inovatif.

\section{WUJUD KARYA}

\section{Pacitanian Art-Edu}

Definisi

Pacitanian adalah sebutan bagi hasil budaya berbentuk 
himpunan besar alat-alat paleolitik yang ditemukan di Sungai Baksooka Pacitan, dengan homo erectus sebagai pendukungnya, dan mempunyai ciri khas prototipe yaitu tidak menghilangkan kulit batu atau kortexnya. (Harry Widianto dan Truman Simanjuntak, 2013:123).

Pacitan Art-Edu merupakan sebuah model pendidikan yang menempatkan fenomena lingkungan alam Pacitan yang menyimpan jejak kehidupan prasejarah di dalamnya, sebagai orientasi utama. Seni dijadikan sebagai wahana, dengan materi latihan ketubuhan di lingkungan alam Pacitan.

Model pendidikan ini menjawab persoalan pelaksanaan pendidikan seni saat ini. Pacitanian Art-Edu merupakan sebuah model pendidikan yang menitikberatkan pada perkembangan kreativitas dan imajinasi anak, serta berorientasi pada fenomena lingkungan alam Pacitan melalui wahana seni.

\section{Alam Pacitan sebagai laboratorium sample}

Kabupaten Pacitan merupakan sebuah kabupaten di dalam wilayah Propinsi Jawa Timur. Terletak di ujung barat daya dari Propinsi Jawa Timur. Wilayah ini merupakan daerah agraris dan sekaligus juga daerah maritim. Hal ini karena wilayah Pacitan terdiri dari pegunungan ataupun perbukitan dan pantai-pantai.

Pegunungan Pacitan masuk ke dalam himpunan Pegunungan Seribu (Gunung Sewu) di jajaran pegunungan karts antara Wonosari dan Jember. Di dalamnya terdapat banyak sekali gua yang menyimpan memori tentang kehidupan manusia prasejarah. Harry Widianto, seorang ahli Paleoanthropologi menyebut Pacitan dengan kerajaan prasejarah. Hal ini dikarenakan Pacitan adalah daerah kaya dan berlimpah alat-alat dari periode jaman yang lengkap mulai paleolitik, mesolitik, neolitik hingga jaman logam. (Wawancara, 10 Januari 2015).

Pacitan memiliki situs prasejarah yang banyak. Salah satu di antaranya adalah Sungai Baksoka, yang terletak sekitar 30 kilometer di sebelah utara Pacitan. Di dasar sungai ini ditemukan himpunan besar alat-alat paleolitik yang kemudian disebut dengan budaya Pacitanian, dengan homo erectus sebagai pendukungnya. Alat-alat yang ditemukan mempunyai ciri khas prototipe yaitu tidak menghilangkan kulit batu atau kortexnya. Situs ini merupakan salah satu situs penting dan terkenal di dunia (Harry Widianto dan Truman Simanjuntak, 2013:123).

Situs-situs gua seperti Song Keplek merupakan situs yang tak kalah penting bagi penelitian tentang kehidupan prasejarah. Song Keplek adalah situs lain di Pacitan di mana telah ditemukan lima individu fosil manusia yang berasal dari ras Australomelanesid dan ras Mongoloid. (Harry Widianto, 2014:81)
Gua di Pacitan telah terbentuk sejak sekitar 15 juta tahun yang lalu, yang sebelumnya berada di kedalaman laut. Selama 15 juta tahun itu gua telah digunakan untuk berbagai kegiatan dari berbagai jenis manusia prasejarah dari jaman yang berbeda. (Harry Widianto, wawancara, 10 Januari 2015).

Selain sungai dan gua, terdapat satu lingkungan yang juga menyimpan jejak prasejarah. Pantai-pantai pesisir dari wilayah Pacitan merupakan sumber situs kehidupan prasejarah. Daerah pesisir adalah wilayah eksploitasi (catchman area) manusia prasejarah untuk pemanfaatan biota laut, perburuan binatang dan pemanfaatan biji-bijian. Fosil biota laut dari pesisir pantai ini banyak ditemukan di dalam penguburan di dalam gua-gua yang tersebar di Asia Tenggara bersama dengan fosil tulang manusia prasejarah. Termasuk juga di dalam situs Song Keplek yang terletak di Kecamatan Punung Kabupaten Pacitan (Simanjuntak, 2004:105).

Data-data tentang fakta ilmiah kehidupan prasejarah yang ada di Pacitan tersebut sangat menginspirasi dan memberikan ide untuk kemudian diwujudkan ke dalam sebuah model pendidikan menuju tujuan pendidikan yang hakiki.

Pentingnya Pacitan Art-Edu

Lingkungan gua, sungai dan pantai sangat mudah memberikan rangsangan emosional atau psikologis dengan cerita takhayul dan mitos. Didukung oleh adanya televisi yang memberikan suguhan tentang cerita seperti ini secara berlebihan, sehingga memberikan efek psikologis negatif kepada anak-anak ketika mereka berada di tiga lingkungan tersebut. Padahal ketiga lingkungan ini dapat memberikan impuls hal-hal yang bersifat rasional, karena merupakan lahan penelitian tentang sejarah.

Pacitan dengan situs-situs prasejarah yang ada di dalamnya, menjadi lahan penelitian tentang sejarah manusia purba. Data dan fakta ilmiah tentang sejarah bumi dan paleoantropologi ini dapat merangsang daya imajinasi anak menjadi lebih rasional.

Kondisi alam Pacitan yang lebih spesifik dengan gua, sungai dan pantai dapat memberikan tantangan kepada anakanak untuk meningkatkan kemampuan dan sensibilitas motoriknya secara maksimal. Batuan yang licin, arus air sungai yang deras, ombak yang kuat, gundukan-gundukan batu dan bukit karang, melatih tubuh anak-anak untuk memiliki fleksibilitas ketubuhan yang optimal. Latihan ketubuhan di lingkungan alam Pacitan menciptakan gaya hidup dimana tubuh berelasi dan harus mengalami cara-cara bergerak yang dibentuk oleh lingkungan alam tersebut. Gerakan-gerakan ini juga dapat mempengaruhi pembentukan syaraf-syaraf otak anak-anak (Sardono W. Kusumo, wawancara, 7 Oktober 2016). 
Dengan demikian, Pacitanian Art-Edu dengan materi latihan ketubuhan di lingkungan alam Pacitan ini dapat menyeimbangkan input emosional anak yang hadir dari cerita takhayul dan mitos dengan input intelektualitas yang hadir dari data dan fakta tentang sejarah manusia purba, serta input motorik sense atau kepekaan ketubuhan yang berelasi dengan lingkungan alam Pacitan.

Pacitanian Art-Edu adalah sebuah persilangan antara Seni, Pendidikan, dan Ilmu Pengetahuan (Kehidupan Prasejarah). Sebuah gagasan baru yang mengawinkan antara keindahan seni, proses regenerasi dan transformasi pengetahuan melalui pendidikan, dan ilmu pengetahuan tentang fakta ilmiah kehidupan prasejarah di lingkungan Pacitan yang juga disebut sebagai kerajaan prasejarah. (Harry Widianto, wawancara, 20 Agustus 2016).

\section{Pelaksanaan Pacitanian Art-Edu}

Pacitanian Art-Edu ini didasarkan pada pendekatan kebebasan bermain dan kenikmatan permainan. Pendekatan ini selalu hadir dan menjadi pijakan utama dalam keseluruhan kegiatan.

Melalui permainan, anak-anak diajak untuk berlatih di lingkungan alam Pacitan. Lingkungan gua, sungai dan pantai ini memberikan tantangan kepada anak dalam kemampuan kepekaan motorik, asosiasi atau imajinasi tentang dunia mitologi, foklor, dan cerita rakyat dan juga kemampuan mendapatkan informasi dengan memanfaatkan teknologi informasi.

Dalam mengembangkan kemampuan kepekaan motorik anak, model ini melatih tubuh anak-anak untuk mengalami perbedaan kepekaan motorik atau kepekaan keinderaan antara gua, sungai dan pantai. Bebatuan yang licin, arus sungai yang deras, lantai dan dinding gua yang dingin, perbedaan ukuran stalagtit dan stalagmit gua, ombak yang kuat, dan hamparan pasir di pantai melatih motorik anakanak melalui keinderaan mereka. Dengan kata lain, latihan ini menyeimbangkan sensibilitas keindraan anak-anak.

Lingkungan alam Pacitan yang berbentuk gua, sungai dan pantai dapat meningkatkan kebebasan asosiasi ataupun imajinasi anak tentang dunia mitologi, foklor dan cerita rakyat. Ketika bermain di lingkungan ini anak-anak secara bebas dan spontan dapat mengimajinasikan cerita-cerita baik yang berbentuk mitos, foklor ataupun cerita rakyat. Bahkan imajinasi mereka juga secara spontan dapat membayangkan tentang dunia fiksi ilmiah seperti "Jurasic Park", "Kingkong" dan sebagainya.

Lingkungan alam Pacitan dapat merangsang anak untuk mencari informasi seluas-luasnya tentang hal-hal yang ditemukan di lingkungan tersebut dengan memanfaatkan teknologi informasi. Seperti halnya anak-anak dengan cekatan menggunakan internet untuk mencari informasi tentang batuan yang mereka temukan di Sungai Janglot.
Pacitanian Art-Edu dimulai pada pukul 08.00 WIB di Sungai Janglot, kemudian berlanjut ke Gua Tabuhan, dan berakhir pada pukul 18.00 WIB di Pantai Srau.

\section{Pendidikan seni di sungai (Sungai Janglot)}

Awal: Anak-anak berjalan beriringan menyusuri pematang sawah. Kondisi pematang sawah yang licin melatih kaki anak-anak untuk berjalan dengan tehnik jari kaki mencengkeram tanah. Sedangkan pematang yang sempit melatih keseimbangan tubuh anak-anak, supaya tetap berjalan di atas garis pematang dan tidak tergelincir. Dengan memakai kaos berwarna putih dan meliuk-liuk mengikuti lika-liku pematang sawah yang hijau dipenuhi tanaman padi, memberikan kesan visual yang sangat menarik. Jarak yang tidak sama antara anak yang satu dengan yang lain, terlihat kadang merapat, kadang melebar menyiratkan adanya variasi kecepatan dari masing-masing anak. Suara-suara burung dan suara pengusir burung dikumandangkan anak-anak secara bersautan. Jarak yang tidak sama antara anak dengan penonton menghasilkan dimensi suara yang timbul dan tenggelam bersamaan dengan hembusan angin di tengah hamparan sawah dan seakan berlomba dengan bunyi gemericik aliran sungai Janglot. Dimensi suara yang dihasilkan anak-anak bersamaan dengan suara alam sungai Janglot ini memberikan kesan auditif yang liar dan terkadang memekakkan telinga.

\section{Eksplorasi sungai}

Anak-anak masuk ke dalam sungai dengan berlari. Tehnik berlari yang mereka gunakan adalah dengan mengangkat kaki tinggi-tinggi di atas permukaan air. Tehnik berlari seperti ini membuat langkah mereka lebih ringan karena tidak terhalang oleh aliran air. Dan air menghambat hunjaman kaki mereka sehingga tidak terluka oleh batuan atau benda-benda di dalam permukaan air. Suara kaki-kaki yang masuk ke dalam air dan teriakan-teriakan anak-anak ini membuat suasana menjadi riuh rendah. Air yang semula sangat jernih, secara tiba-tiba menjadi keruh. Tak lama kemudian anak-anak terbagi menjadi lima kelompok dan melakukan aktivitas masing-masing bersama kelompoknya. Ada yang menyelam, mengambang, meloncat antar batu, merangkak, dan memainkan suara air. Semua aktivitas anak bermain air yang natural ini menyampaikan isyarat tentang kesegaran. Aktivitas anak yang terkadang berkelompok, dan terkadang menyebar menyiratkan adanya variasi komposisi gerak anak.

Mandi bersama teman dan hewan peliharaan

Empat ekor kambing dituntun oleh empat orang petani dusun Janglot masuk ke dalam sungai Janglot. Beberapa anak mendekati mereka. Beberapa saat kemudian mereka sudah asyik memandikan kambing-kambing tersebut. Salah seorang petani bahkan mengajak anak-anak untuk bermain bersama kambingnya. Dua kaki depan kambing di angkat sehingga posisi kambing berdiri dan berjalan dengan dua kaki layaknya manusia. Anak-anak tertawa lebar menyaksikan hal tersebut. Lalu seekor sapi dituntun masuk 
ke dalam sungai. Melihat keasyikan anak-anak yang telah bermain bersama kambing-kambing sebelumnya, anakanak yang lain dengan semangat berlari mendekati sapi tersebut. Tanpa komando mereka langsung menciprat-cipratkan air ke sapi tersebut sambil berteriak-teriak kegirangan. Melihat tingkah anak-anak yang terlalu bersemangat tersebut, sapi menjadi agresif. Bergerak kesana-kemari sambil menghentak-hentakkan kaki seperti akan berlari. Anak-anak menjadi takut dan berteriak-teriak menjauhi sapi tersebut. Melihat hal ini, petani pemilik sapi ini menyadari bahwa sapi menjadi kaget dan stress karena tingkah anak-anak. Kemudian petani mengajak anak-anak tersebut menenangkan sapi tersebut dengan tidak berteriak-teriak dan tidak menciprat-cipratkan air ke tubuh sapi. Petani mencoba mengelus-elus kepala sapi. Usaha tersebut sedikit membuahkan hasil. Sapi menjadi agak tenang. Secara perlahan anak-anak mendekati sapi kembali dari samping dan memandikan sapi tersebut secara hati-hati. Kegiatan ini menggambarkan adanya kegembiraan anak-anak bermain bersama teman dan juga hewan peliharaan manusia. Di dalamnya tersirat hubungan antar manusia dan antara manusia dengan hewan peliharaan.

\section{Eksplorasi batu-batuan}

Kegiatan ini dimulai ketika seorang anak menemukan sebuah batu besar berwarna cokelat, yang agaknya berbeda dengan batu lainnya yang berwarna hitam. Anak tersebut memanggil teman-temannya untuk menunjukkan batu tersebut. Proses memanggil teman ini dilakukan dengan berteriak secara berantai, hingga akhirnya anak-anak berkumpul mengelilingi batu besar yang ditunjukkan oleh anak tersebut. Kemudian terjadi dialog di antara mereka untuk menganalisa batu tersebut. Beberapa saat kemudian anak-anak menyebar ke berbagai arah untuk mencari batuan serupa. Tak berapa lama, anak-anak menemukan banyak sekali batuan serupa dengan ukuran yang lebih kecil. Salah seorang dari mereka kemudian mengajak bermain menumpuk batu. Secara berkelompok kemudian mereka mencoba menumpuk batu-batu yang mereka temukan. Hasilnya mereka imajinasikan menjadi berbagai bentuk, seperti: Menara Pithecantropus, Istana Homo Sapien, Gua Manusia Purba, dan Tombak Manusia Purba. Permainan menumpuk batu ini melatih kerjasama, keseimbangan, dan kebebasan berimajinasi. Rangsangan batu-batu rijang dan batu fosil yang mereka temukan menggiring imajinasi mereka kepada kehidupan prasejarah, sehingga nama-nama hasil karya mereka juga mengandung unsur kehidupan prasejarah.

\section{Dunia kamera dan internet}

Kegiatan ini dimulai ketika salah seorang anak menemukan kapak persegi dari permainan menumpuk batu yang telah mereka lakukan. Anak tersebut kemudian memanggil teman-temannya untuk menunjukkan penemuannya. Setelah berkumpul, secara bergiliran anak-anak mencoba untuk melihat dan memegang batu tersebut. Lalu mereka bertanya-tanya batu apakah itu. Salah satu diantara mere- ka mengajak untuk browsing. Dan sesaat kemudian secara berkelompok mereka mencoba untuk mencari tahu tentang batuan yang mereka temukan beserta sejarah yang tersimpan di dalamnya. Setelah menemukan apa yang mereka cari sejenak kemudian anak-anak mendokumentasikan hasil karya tumpukan batu mereka beserta anggota kelompoknya ke dalam foto-foto dari kamera handphone mereka. Kegiatan ini menggambarkan adanya pemanfaatan teknologi informasi untuk lebih mengetahui dan memahami tentang lingkungan tempat hidup mereka yang ternyata menyimpan potensi tentang sejarah evolusi manusia atau tentang kehidupan prasejarah.

\section{Rumah ranting}

Kegiatan dimana anak-anak merekonstruksi rumah yang dibuat oleh Homo Erectus pada jaman Paleolitikum di daerah terbuka sepanjang aliran sungai, yang bentuknya mereka lihat di dalam film "Walking with Cavemen". Rumah tersebut terbuat dari ranting-ranting pohon lengkap dengan daun-daunnya. Anak-anak yang semula beraktivitas di dalam aliran sungai, pada kegiatan ini mereka semua menuju ke pinggir sungai. Secara berkelompok mereka bekerja sama membuat tiga rumah. Beberapa anak bertugas untuk mencari dan mengumpulkan ranting-ranting yang berserakan di sepanjang aliran sungai. Beberapa anak bertugas untuk mendirikan dan membentuk rumahnya. Tetapi beberapa anak laki-laki lebih asyik berkelompok membuat mahkota dari daun dan bermain manjadi raja yang menunggangi sapi yang berlomba kecepatan, dan akhirnya setelah rumah ranting yang dibuat oleh teman-temannya jadi, raja-raja dan sapi-sapi ini kemudian disuruh masuk ke dalamnya. Kegiatan ini selain melatih tentang kerjasama, juga melatih anak untuk memanfaatkan lingkungan sebagai media permainan yang menarik, pembagian tugas secara adil, dan kompetisi yang sportif. Permainan

Anak-anak bermain memanfaatkan rumah ranting yang telah mereka buat. Dengan membuat lingkaran yang berbentuk lonjong mengikuti kontur tanah lapang yang ada, mereka bergerak mengikuti aturan permainan gerak berkelompok. Setelah satu putaran, ditemukan beberapa anak yang harus dihukum. Hukumannya adalah bergerak dan bersuara binatang mengikuti komando dari pimpinan permainan. Hukuman ini dilakukan di dalam sungai. Meski dengan malu-malu karena mendapat olok-olok dari teman mereka yang tidak dihukum, mereka bergerak berdasarkan imajinasi masing-masing tentang gerak dan suara binatang yang disebutkan oleh pimpinan permainan. Mereka menirukan monyet, buaya, burung dan binatang lainnya. Gerak-gerak yang mereka hasilkan sangat lucu sehingga menimbulkan gelak tawa teman yang lain dan juga penonton. Kegiatan ini mendidik sikap sportif dan menerima kekalahan.

\section{Pendidikan seni di gua (Gua Tabuhan)}

Kondisi ruang-ruang gua yang gelap, dingin, udara yang 
apak, dengan lantai yang becek dan licin memberikan rangsangan yang berbeda dibandingkan lokasi pertama yaitu sungai Janglot.

\section{Awal}

Kegiatan dimulai dengan membuat reportase tentang gua Tabuhan. Secara berpasangan anak berperan sebagai reporter dan juru kamera. Berbekal handphone untuk merekam video dan microphone, mereka membuat reportase pembuka tentang Gua Tabuhan, baik secara fisik dengan stalaktit dan stalagmitnya, maupun sejarah kehidupan prasejarah dengan alat-alat batu dan fosil yang telah ditemukan di dalam gua tersebut.

Merangkak di batuan mulut gua

Dari dalam gua sekelompok anak laki-laki berjalan merangkak dalam satu garis meliak-liuk. Mereka kemudian menghilang di balik gundukan batu-batu besar di mulut gua. Sesaat kemudian mereka muncul dari berbagai arah dengan merangkak-rangkak di atas batu-batu besar tersebut. Tanpa rasa takut mereka memanjat batu dengan ketinggian kurang lebih tiga meter dan kemiringan $90^{\circ}$. Setelah sampai di atas mereka merangkak turun pada sisi belakang gundukan batu yang licin tersebut. Anak-anak dengan lincah merangkak dan meloncat di antara batu. Mereka mengeluarkan suara melengking seperti kera dan burung-burung. Gerak merangkak di batu-batu besar ini melatih otot-otot tangan, kelenturan dan ketangkasan tubuh anak-anak.

\section{Masak-masakan}

Ruangan ini diapit oleh dua lubang ekskavasi tempat penelitian tentang kehidupan prasejarah, dimana ditemukan tulang-tulang kera, dan juga fosil-fosil kerang. Tulang kera yang dimaksud disini merupakan jenis Macaca sp, yang sangat disukai manusia prasejarah sebagai makanannya (Harry Widianto, wawancara, 20 Agustus 2016). Berdasarkan data ilmiah ini, maka dapat diinterpretasikan ruangan tersebut sebagai ruang makan atau ruang tempat berkumpul keluarga bagi manusia prasejarah. Sehingga memberikan inspirasi untuk menggunakan ruang tersebut sebagai ruang aktivitas permainan masak-masakan bagi anak-anak.

Setelah memasuki mulut gua, pada sisi sebelah kanan terdapat sekelompok anak yang duduk melingkar. Tangan mereka memegang alat permainan masak-masakan berwarna-warni. Sesekali mereka berpindah tempat seakan-akan mengambil sesuatu seperti air atau bahan makanan ataupun memberikan hasil masakan pada temannya. Anakanak ini terlihat asyik bermain masak-masakan sambil bercakap-cakap. Dalam percakapan mereka ditemukan sesuatu yang menarik. Anak-anak tersebut ada yang sedang berimajinasi sedang memasak sate Macaca sp, kera ekor panjang yang menjadi makanan favorit manusia prasejarah. Dalam percakapan tersebut, disebutkan pula informasi yang sangat penting bahwa di dalam gua tidak diperboleh- kan membawa api. Dalam kegiatan ini, anak-anak berimajinasi seluas-luasnya tentang kegiatan manusia prasejarah berkumpul, memasak dan makan bersama keluarganya di dalam ruangan gua tersebut. Imajinasi mereka menjadi tupang tindih antara realitas sejarah kehidupan prasejarah yang terjadi di waktu lampau dengan kehidupan mereka sehari-hari saat ini.

\section{Wayang purba}

Sekelompok anak laki-laki sedang bermain-main wayang purba. Anak-anak tersebut bercakap-cakap bebas, menangkap fenomena yang terjadi di sekitar menjadi bahan pembicaraan mereka. Dalam kegiatan ini, anak-anak diajak untuk dapat bermain peran dan berimajinasi seluas-luasnya. Hal yang menarik dalam kegiatan ini adalah imajinasi mereka menjadi tupang tindih antara realitas sejarah kehidupan prasejarah yang terjadi di waktu lampau, dan realitas kejadian yang terjadi di sekitar gua Tabuhan pada saat yang sama.

\section{Permainan bunyi batu}

Kegiatan ini diisi oleh sekelompok anak yang menabuh stalaktit-stalagtit gua Tabuhan. Tetabuhan mereka menghasilkan satu bentuk ensamble musik batu sederhana. Beberapa anak bergabung, berjoget sambil menyanyikan lagu Wèk Wèk Gung dan Nenek Moyangku. Kegiatan ini melatih kreatifitas anak dan melatih sensibilitas, serta musikalitas ketubuhan anak.

\section{Fosil Bergeletakan.}

Di Gua Tabuhan terdapat cekungan yang letaknya terpisah dan agak ke dalam. Lantai ruangan ini becek dan sangat licin karena banyak sekali air yang menetes dari stalaktit di atasnya.

Kegiatan ini dimulai ketika sekelompok anak-anak bergeletakan di lantai gua di dalam cekungan. Tubuh mereka bergetar seperti kedinginan. Sesekali mereka berpindah tempat dengan merangkak. Lantai yang becek membuat pakaian mereka menjadi berwarna cokelat penuh lumpur. Kegiatan ini mengajak tubuh anak-anak untuk merasakan dingin, becek, dan licinnya lantai gua secara langsung. Gerak tubuh yang bergetar, bergeletakan, dan merangkak di lantai gua menyiratkan rasa lembab dan dingin yang menusuk tulang.

\section{Permainan Kodok}

Sekelompok anak-anak melompat-lompat di atas batu. Mereka bersuara seperti kodok sahut-menyahut. Anakanak berimajinasi menirukan binatang katak/kodok yang mereka temukan di mulut gua. Suara menirukan kodok yang sahut menyahut dengan posisi anak yang bervariasi menghasilkan dimensi suara yang bervariasi pula. Kegiatan anak ini memberikan kesan seperti ensamble suara kodok ketika musim hujan tiba.

\section{Permainan Sriti}

Aktivitas sekelompok anak-anak bermain dengan bayan- 
gan dari tubuh mereka, menirukan binatang Sriti yang banyak terdapat di Gua Tabuhan. mereka berlari-lari kecil dan menggerakkan kedua tangan seperti ingin menggambarkan burung yang sedang terbang. Mereka mengeluarkan suara seperti burung Sriti yang memekakkan telinga. Sorot lampu penerangan yang menerangi lambaian tangan sekelompok anak ini menghasilkan bayang-bayang di dinding gua. Hal ini membuat anak semakin asyik untuk menjadikan bayang-bayang tersebut menjadi media permainan mereka.

\section{Permainan suara sahut-menyahut}

Anak-anak bermain gema dari suara yang mereka hasilkan bersama teman-teman di dalam ruangan yang berbeda-beda secara sahut menyahut. Kegiatan dimulai dengan kelompok permainan Kodok yang bergerak dan bersuara seperti kodok, lalu disusul kelompok permainan Fosil yang bergerak merangkak dan bersuara seperti petani mengusir hama (hiya...hiya..), disusul oleh kelompok permainan masak-masakan yang bergerak melompat-lompat dan bersuara buuuuaakkk...buuuuaaakkk..., di susul oleh kelompok permainan Sriti yang bergerak seperti burung dan bersuara seperti burung. Suara anak-anak ini sahut-menyahut memenuhi seluruh ruang gua Tabuhan, menghasilkan dimensi suara yang berbeda-beda dan memekakkan telinga.

\section{Permainan Sriti 2}

Anak-anak berkumpul di tengah ruangan. Mereka menggerakkan tangannya dan berlari kecil seperti menggambarkan burung yang sedang terbang. Mereka membentuk formasi melingkar dengan satu anak berada di tengah. Anak-anak bergerak melingkar, duduk, berdiri dan berlari dengan tangan tetap seperti gerakan kepakan sayap burung. Lantai yang sangat licin membuat beberapa anak jatuh terpeleset, tetapi dengan segera mereka bangkit kembali dan mengejar teman mereka. Suara anak-anak yang menirukan suara burung Sriti ini terdengar memekakkan telinga dan memenuhi setiap sudut ruang gua Tabuhan untuk beberapa saat.

\section{Permainan “Joringan” (Petak Umpet)}

Dalam permainan ini, anak-anak menjelajah dan mengekplorasi ruang-ruang Gua Tabuhan. Mereka bersembunyi di balik gundukan batu, stalaktit maupun stalagmit. Anakanak dilatih untuk memiliki kecerdasan dan ketangkasan tubuh dengan menyesuaikan tubuh mereka ke dalam ruang sempit, bahkan juga melipat tubuh mereka supaya tidak kelihatan.

\section{Dunia kamera}

Kegiatan ini adalah aktivitas anak-anak yang bermain secara berkelompok, dimana aktivitas ini direkam menjadi sebuah video yang pada akhirnya akan mereka lihat bersama-sama. Anak-anak dibagi menjadi empat kelompok, dengan permainan sebagai berikut: Géndhongan (anakanak berpasangan dengan cara seorang anak menggendong anak yang lain, dan berlomba adu kecepatan), Wèk
Wèk Gung, Kuda-kudaan (anak-anak berpasangan, seorang anak menjadi kuda yang berjalan merangkak, seorang anak lain menjadi penunggang kudanya, dan berlomba adu kecepatan). Selain aktivitas fisik, kegiatan ini juga melatih anak-anak untuk memanfaatkan teknologi kamera handphone menjadi media permainan yang menarik.

\section{Penutup}

Mereka berbaris beriringan dengan memegang pundak temannya keluar gua Tabuhan dengan menyanyikan lagu Nenek Moyangku.

\section{Pendidikan seni di pantai (Pantai Srau)}

Hamparan pasir lengket, angin yang bertiup kencang tapi lembab, gulungan ombak dengan air yang asin menyapu pantai, memberikan rangsangan yang berbeda dari lokasi pertama dan kedua.

\section{Arak-arakan warna}

Anak-anak menjelajah bukit-bukit karang, membawa bambu seperti alat pancing dengan bendera kain warna warni yang dapat mereka gunakan sebagai tongkat yang membantu menyangga tubuh mereka ketika berjalan. Mereka juga memakai jas hujan warna-warni, dan berjalan beriringan. Pada bagian ini, anak-anak diajak untuk mengenal lingkungan pantai Srau hingga ke atas laut dalam. Anak-anak dapat melihat laut lepas dari atas bukit. Mereka juga dapat melihat secara langsung bagaimana perjuangan para nelayan pantai Srau memancing ikan dari atas bukit karang dengan menggunakan bilah bambu seperti yang mereka bawa. Kegiatan ini selain memberikan latihan fisik kepada anak-anak, dan memberikan pengetahuan tentang kehidupan nelayan secara langsung, akan tetapi juga memberikan kesan artistik yang mendalam melalui warna-warni yang mereka bawakan ditengah hamparan bukit karang yang hijau tertutup oleh semak-semak.

\section{Eksplorasi lingkungan pantai}

Kegiatan ini diawali dengan anak-anak menancapkan bambu dengan bendera warna-warni yang mereka bawa di pasir secara berjajar. Beberapa anak menancapkan bambu mereka di bagian paling ujung dengan posisi menggerombol. Sehingga pola bambu yang ditancapkan membentuk garis melengkung mengikuti garis pantai, dan di ujung terdapat bambu yang menggerombol, sedangkan di ujung yang lain telah berdiri sebuah rumah warna. Berbentuk seperti rumah suku Indian Amerika, akan tetapi dindingnya terbuat dari jas hujan warna-warni. Sesaat kemudian anak-anak bermain bebas dengan berkelompok. Sekelompok anak bermain mengikuti jejak. Mereka berbaris dan meloncat-loncat mengikuti jejak kaki teman di depannya. Dua kelompok anak yang lain bermain merangkak dan merayap, dan meninggalkan jejak meliak-liuk tanpa putus. Sekelompok anak lainnya berguling-guling, mengangkat kaki dan sekali-kali meloncat bersama-sama. Di bagian paling ujung utara pantai, sekelompok anak bermain Péncok-péncokan. Satu anak yang dadi akan berusaha untuk 
memegang temannya yang berlarian menghindarinya. Permainan ini terus berlanjut hingga anak yang dadi bisa memegang salah satu temannya, dan temannya tersebut menjadi anak yang dadi.

Kegiatan ini sangat kental dengan latihan fisik yang dilakukan dengan berbagai cara, akan tetapi tetap berpegang pada pendekatan kebebasan bermain dan kenikmatan permainan. Anak-anak tetap dapat mengekspresikan diri mereka secara bebas, dan hal ini menimbulkan efek rasa senang yang dapat kita lihat dari pancaran wajah anak-anak.

Gambar pasir, patung pasir, dan craft biota laut Kegiatan ini diwali dengan aktivitas anak-anak melepaskan jas hujan warna-warni yang mereka pakai. Kemudian secara berkelompok anak-anak membentuk bangun datar besar yaitu segitiga, segi empat, dan lingkaran, dari jas hujan yang mereka tanam di pasir. Setelah itu, beberapa anak masuk ke dalam bangun datar tersebut untuk menjadi model patung pasir yang dibuat oleh teman-temannya yang lain. Beberapa anak yang lain terlihat asyik membuat gambar pasir di sepanjang garis bambu yang mereka buat sebelumnya. Beberapa anak yang lain asyik mencari kerang, terumbu karang, daun-daunan, buah pandan dan benda-benda lain di sepanjang pantai, untuk kemudian diserahkan kepada beberapa anak yang telah siap dengan kertas karton, lem dan krayon paster. Setelah terkumpul, kemudian mereka bekerja sama membuat craft biota laut. Ada yang menggambar sketsa di kertas, ada yang mewarnai kerang dan terumbu karang, ada yang melumuri kertas karton dengan lem, dan secara bersama-sama menempelkan kerang, terumbu karang, dan benda-benda laut lainnya ke kertas karton. Dari masing-masing kelompok yang ada, mereka seperti berkompetisi untuk membuat karya yang indah.

Bebakaran ikan

Sebuah kegiatan kesibukan anak-anak membakar ikan pada perapian panjang yang telah disiapkan. Setelah siap, maka masuk ke dalam kegiatan makan bersama. Tempat makan telah disiapkan berupa daun pisang utuh memanjang sepanjang kurang lebih 10 meter. Di atas daun pisang telah diberi nasi putih dan sambal. Anak-anak kemudian duduk berhadapan menghadap daun pisang, dengan membawa ikan yang telah mereka bakar. Sesaat kemudian mulailah kegiatan makan bersama. Kegiatan ini mendidik anak tentang nilai kebersamaan, kerja sama, tenggang rasa, dan berbagi.

Api unggun

Dengan mengelilingi api unggun, anak-anak berjoget bersama dengan iringan lagu melayu "Lungset" yang syairnya mereka gubah menjadi bercerita tentang aktivitas yang telah mereka lakukan sejak pagi. Kegiatan ini menjadi puncak dari seluruh kegiatan. Anak-anak mengungkapkan kegembiraan mereka dengan berjoget dan bergerak bebas sesuai dengan keinginan mereka masing-masing, tanpa rasa lelah.

\section{SIMPULAN}

Pacitanian Art-Edu dapat menjadi rujukan dan pedoman dalam pelaksanaan pendidikan seni sehingga dapat mengarahkan pola pendidikan seni ke jalur yang sesuai dengan hakikat tujuan pendidikan seni, di mana kreativitas dan potensi anak-anak sangat penting untuk dimaksimalkan sesuai dengan potensi yang dimiliki oleh lingkungan. Model ini merupakan sumbangan alternatif dan memperkaya praktik pendidikan seni untuk anak-anak di pendidikan formal. Model ini juga memberikan inspirasi terhadap terciptanya ide-ide pengembangan tentang pelaksanaan pendidikan seni di lembaga pendidikan baik formal maupun non formal.

\section{DAFTAR RUJUKAN}

Hamalik, Oemar. (2003). Proses Belajar Mengajar. Jakarta: PT. Bumi Aksara.

Latif, Yudi. (2016). Pendidikan yang Tidak Mendidik. Kompas, Kamis 4 Agustus 2016.

Simanjuntak, Truman dkk. (2004). Prasejarah Gunung Sewu. Jakarta: Ikatan Ahli Arkeologi Indonesia.

Widianto, Harry. (2011). Nafas Sangiran Nafas Situs-Situs Hominid. Sragen: Balai Pelestarian Situs Manusia Purba Sangiran.

Widianto, Harry dan Truman Simanjuntak. (2013). Sangiran Menjawab Dunia. Sragen: Balai Pelestarian Situs Manusia Purba Sangiran.

Widianto, Harry. (2014). Jejak Langkah Setelah Sangiran. Sragen: Balai Pelestarian Situs Manusia Purba Sangiran. 